\title{
Adaptation of Municipalities to The Spatial Evolution of Skënderbegas Commune, Albania
}

\author{
Qamil Lirëza \\ Department of Geography \\ "Aleskander Xhuvani" University, Elbasan, Albania \\ e-mail:liptongreg@yahoo.com
}

DOI:10.5901/mjss.2014.v5n22p114

\begin{abstract}
The article presents an accurate scientific assessment of the physic-geographical, historical, socio economic and cultural assessment of Skënderbegas commune, Albania. The main purpose of this paper is to present these components in different time stages, by noting new qualitative elements. For the composition of this article we are based on a long observation and research work, across the geographical area of this commune, as well in terms of natural, demographic, cultural and economic aspect. An important role has had the numerous surveys have been conducted with the local residents, as well the use of an extensive literature related to subject of study. At first, it is provided a general assessment of the geographical position, landscape, geological construction, climate, hydrography, soils and vegetation. Further, it is made an analysis of the population of all the villages of the commune in question, highlighting the different rhythms the population from 1926 to 2013 , and providing explanations for the decline in number of the reside each village. To demonstrate this performance, a chart is compiled, and respective analysis is done. An important place occupies the evaluation of patriotic and intellectual figures of this commune, their contribution to independence and freedom. Further it is made an assessment of the economy and lifestyle of these inhabitants, pointing out the problems that they have. At the end of the article are given the general conclusions and recommendations.
\end{abstract}

Key words: evolution, population, nature, economy, lifestyle

\section{Introduction}

The commune is located in the south district of Gramsh, in the central part of Albania. The total area of the commune is $80.1 \mathrm{~km} 2$. Skenderbegas commune includes 13 villages which are: Skëndebegas, Bletëz, Ermenj, Fushëz, Harunas, Kotka, Kullollas, Lemnushë, Nartë, Siman, Shëmbërdhenj, Vidhan and Zenelas. It is situated on this geographical coordinates: northern latitude is 40043'15' and 40048'52" while eastern longitude is 20012'19" and 20017' 22". From archaeological evidence it results that in some villages of this commune, there have been early settlements, such as in Vidhan and Skenderbegas villages, where their tracks date the VII-VI century BC. The center of the commune is located $17 \mathrm{~km}$ from the city of Gramsh and $50 \mathrm{~km}$ from Çorovoda city.

According to local inhabitants the denomination of several villages result as follows: The name Skënderbegas is linked to the legend of passage of the "national hero Skanderbeg" with his army during the fifteenth century. The name of Bletëz relates with the presence of many bees in that village. The name of Shëmbërdhenji, according to the renowned archaeologist Neritan Ceka (Tirana), comes from St. Mbërdhirët, identified with 40 Saints, who died wrapped in a frozen lake of Sebasties (Ceka N). The name of Nartë is known even in other territories of the country. Referring to Siman name, it was formerly called Sqimar, even now it is still used by the elderly with that name. Similar denomination is found in Indonesia, Iran, Pakistan and Mali.

\section{Method}

During the drafting of this article, we are based on the method of direct observation in the geographical area of this commune, studying closely; its nature, geological construction, landscape, climatic conditions, soils and vegetation. Also an important attention is occupied by the research methods based on the documentary data of the past, as well as the current ones. To assess as more accurately the time stages of development for this municipality, many questionnaires have been compiled with the inhabitants of these villages, where 
many important conclusions have been drawn. The basic resource materials are obtained from the archives of this municipality, the registrar's office, the district's archive, various editions such as; The monographic "The nature and people in Tomorrica province ", "Tomorri in front of us" etc.

\section{Results}

The geological construction of the territory is simple. The geological structures are Tomorricë-Devolli syncline (western side) with Paleogene flysch rocks) (Middle Oligocene). In Tomorica's syncline there is a decrease, mainly, 10-150, whereas in Devolli's one up to 600. In southeast the flysches have tectonic contact with the covering structure of Koshnica Mountain. The geological construction is spoken more specifically in the monograph "The Natural Heritage of Tomorrica", which is written by Lireza. Q and Sala. S. The sandstone cliffs are widely used for the building and covering of the houses, walls, yard, etc, while clay-alevrolit rocks are used for handicraft production (a few) of tiling and bricks. A long time ago, it was even used for the preparation of crocks.

The geological construction and surface leaks have defined the morphological features and geomorphologic processes of the slope. The main forms of the landscape are hills and valleys. Their feature is the scalable morphology (peak, quaestor hills). Heights stagger is from 250-260 m (valley of Tomorica) to $638 \mathrm{~m}$ (south of the village).

In the flichy territory there are limestone blocks (olistolite). Sandstones are used for the building and covering of the houses (slate), limestone for lime. They are both used in erosion mounds, wall buildings; etc. The landscape is hilly- pre-mountain. It is formed by flysch with morphological escalations (Lirëza \& Sala, 2013).

The quaesto landscape (5-6 peaks) is best expressed in the sector toward the peak Bregu Maise (618.2 $\mathrm{m}$ ) and the neighbourhood Shimër-Tomorricë valley (7 foothill- quaesto). Ridges are built by the sandstone-conglomerates. Subsequent pass between them (width about 250-300 m) in the clay-alevrolite packages are used for pedestrian and rural roads. The landscape has an average degree of horizontal fragmentation up to $3 \mathrm{~km} / \mathrm{km} 2$ in northwest of Shimër while in the southeast; it goes up to $4-5 \mathrm{~km} / \mathrm{km} 2$. In this area are formed some small foci of erosion. The reforestations around 30 years ago have limited their expansion. They are surrounded by arable land. In general, the slopes have a small average incline, therefore it is facilitated the expansion of arable land.

The valleys are represented a little from Tomorrica's one and its branches on this slope (Shtegu i Lerës, etc). Generally, in the slopes proceed natural vegetation and a few geomorphologic processes of the slope. Near and around the village, over 100 years ago, the natural vegetation began to be replaced by arable land. Sloping backs with small inclines are preferred and chosen for the construction of houses (the streams of Shkollas and Shimëri, Shtegu i Leres).

The valley $(2.5-3 \mathrm{~km})$ in the east-west part is obsequent. It has almost symmetrical slopes and winding due to lithological causes. In the river bed, there are identified small rapids. On the northern slope, the vegetation decreases, the agriculture expands the erosion and slides increase. In the south of the valley (the branch of Kurajt: 2-2.5 km) are identified the same morphological characteristics, but differs on better storage of the vegetation in the basin. The black pine arrives near the valley of Tomorrica.

It is included in the Mediterranean- hilly climate area. (HIDMET Institute, 1984). The geographical position makes it open to the winds and a significant number of sunny hours radiates on it. However, Tomorri Mountain deprives of sunny time in late afternoon at winter. Small heights of landscape do not allow lower temperatures, excluding extraordinary meteorological events.

The hydrography in the commune of Skënderbegas is represented by the upper part of some left branches of Devolli, the right branches of Tomorricë (Shtegu Lerës, Shesë, Gurrës, Përroi i Thellë, Kostonisë Shpellës, Sekës ) and some other resources. Those are short, but the ones that are discharged on Tomorrica are longer and not with a small bed incline. Lera's Path $(3 \mathrm{~km})$ starts near the Mais hill $(618 \mathrm{~m})$ and ends in Tomorrica $(270 \mathrm{~m})$. Near the village, the two main branches unite at $510 \mathrm{~m}$ altitude. These are temporary in the case when Lera's Path is fed by small resources.

The genetic types of lands are represented by: brown gray, brown and auburn forestry lands, but the most dominant is the first type (up to $600 \mathrm{~m}$ altitude). It has the largest agricultural uses that are liked for many agricultural crops. In the last 20 years olive is added too. The two other types have limited extent and only a few by brown lands are used in agriculture. The vegetation of shrubs are better preserved in northern of Shkollas, on the left of rural roads and on west of Shimër neighbourhood (small areal). It seems clear that the expansion of arable land has influenced a lot. The pine forest of Skënderbegas (32 ha) extends in the heights from 400 to $500 \mathrm{~m}$ up to $1500 \mathrm{~m}$ (Qiriazi and Sala, 2007), it is well 
preserved, but the fire (August 2008) significantly damaged its surface (on right of the rural road)

The wild fauna is rich, relatively well (wolf, fox, rabbit, hedgehog, marten, badger, weasel, etc.). Brown bear and boar are visitors on winters with heavy snow, when they go down to the village; they harm the livestock and maize. There are plenty of birds (partridges, falcons, wild pigeon, jay, blackbirds, sparrows, nightingale, turtledove, owl, cuckoo horse, etc). However, inappropriate hunting of the last 15 years is damaging the wild fauna (hunters from the districts, and even foreigners). They shoot at any time by killing as much as they can without paying taxes at the commune. Illegal hunting damages the welfare of the inhabitants too.

Nature has been kind with this commune (climate, forest, fauna, landscape), but the commune and residents have to change the way of use, made so far in favour of nature and socio-economic opportunities. Skënderbegas is connected with rural roads as Gramsh, Bletëz, Ermenj, Vidhan, Fushëz, Zenelas, Siman etc. There is a daily transportation line Gramsh -Vidhas - Gramsh. There are 10-12 private cars (various types) and 2-3 tractors for agricultural work (higher cost). The electricity system is linked with those of Kodoviat and Kërpica and supports well the present loads, despite the increasing use of household electrical appliances (rural exodus). The power is used for showers and rarely for cooking. Residents like the wood warming (low cost). However, it is verified that inhabitants pay regularly the electricity that they consume.

\section{Population in years}

In 1926 there were 650 inhabitants in Skënderbegasi (Selenica, 1927) while in 2010 there were 439 inhabitants (217 males, 222 females) and over 100 economic immigrant males).

In 1926 the village of Narta had 127 inhabitants, in 1989 there were 400 inhabitants, in 2012 there were 333 inhabitants (163 males and 22-25 third ages). In 1926 there were 115 inhabitants Kotka village (Selenica, 1927). After 1990 many inhabitants have left their residence toward: Greece(8-10 people) Italy (6-7 people) and 3 people in England while referring to the families are identified: 17-20 families in Tirana, 3-4 in Durres and Elbasan, 4-5 is the number of families in Gramsh and 2-3 families in Fier and Vlora.

Harunas village had 164 inhabitants in 1989. After 1991 the population was involved in the emigration and migration. In 2008, there were 143 people (67 males, 76 females in 29 families); in 2012 it had only 80 inhabitants.

Lemnushë village had 45 inhabitants in 1926 (Selenica, 1927) while in 1989 there were 115 inhabitants and in 2012 there were 55 inhabitants (20 females and 12 males). High exodus in search of a better life has reflected the dominance of females. There are identified 25-30 inhabitants who are immigrated to Greece. (The Office of Statistics of Skenderbegas, 2014).

Kullollas village had 83 inhabitants in 1926, all muslims (Selenica, 1927); in 2008 it had 168 inhabitants (75 males, 93 females) and 49 families; in 2010 it had 164 inhabitants (74 males and 90 females, 48 families). Over 20 inhabitants followed the seasonal emigration helped by the visa's liberalization (The Office of Statistics, Skenderbegas, 2014).

Ermenj village had 172 inhabitants in 1926 (Muslims-Bektashi Selenica, 1926), in 1989 there were 486 inhabitants, in 2010 there were 210 inhabitants (110 males and 100 females, 45 families, 20 of them followed seasonal emigration; 2012 it had 140 inhabitants (85 males, 14 pensioners). (The Office of Statistics of Skenderbegas, 2014).

Fushëz village had 136 inhabitants in 2008 (according to gender, equal number) and 40 families; in 2010 it had 119 inhabitants (62 males and 57 females) and 36 families. 10-12 males follow seasonal emigration in Greece. Siman village had 150 inhabitants in 1989, while in 2008 resulted to be 129 inhabitants (47 males and 82 females, 30 families), and in 2012 there were approximately 100 inhabitants. (Basha, P. 2005, In front of us, Tomorri).

Vidhan village had 189 inhabitants, in 2008 there were 154 (81 males, 73 females and 39 families), in 2012 it had only 70 inhabitants (40 males and 30 females). After 1991 around 10 families emigrated to Greece and Italy, 5-6 to Tirana, 2-3 to Durres, Elbasan and Gramsh etc.

Zenelasi village had around 100 inhabitants in 1989, while in 2013 (after 1990 exodus) it remained 35-40 people (gender differences, 2-3 people), 26-30 people have emigrated to Greece, 5-6 families to Tirana and Gramsh, 2-3 to Durres, 2 Elbasan etc. Below is given the graphic that present the population of this commune. 


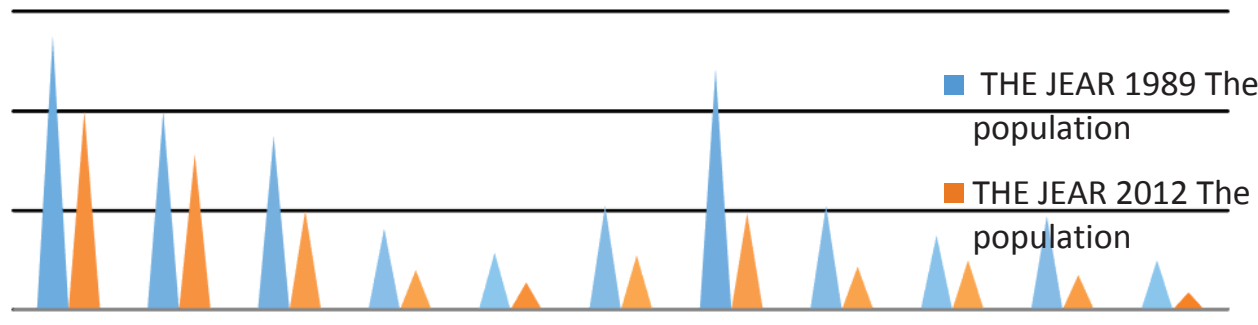

Chart 1. The Performance of the population in the villages of Skenderbegas commune

From the analysis of this chart, it results that from 2008 to 2012 the number of inhabitants in this commune has decreased. This is related to the evacuation from these rural areas toward the urban ones and in emigration.

From this commune have come up many well known figures in national rang. Xhile Liçi is one of the national figures. His name is given to the school and to a neighbourhood in Gramsh. He is relatively less known, so we are giving its main activity.

He was born on 2.01.1878. The economic difficulties forced him to emigrate (around 1895) in Follorine, Selanik, Manastir and other towns in the Balkans and Turkey.

In 1911 he joined with the call of the Great Powers for the independence of Albania and together with Asllan Shahini they represented Tomorrica and Gramsh at the Assembly of Vlora (28/12/1912); they authorized Ismail Qemali as representative for these regions.

Ermenj village is the place of birth of Abas Ermenji (1913-2003), one of the leading figures of the National Front. He made his secondary education in Shkodra. With a scholarship from the state, he went in Sorbon (France) for undergraduates. He worked as a professor at the Lice (1938). He was against the Italian occupation, therefore was arrested and deported (1940) in Veneto island (Italy). One year later, he came back and started organizing the National Front. The patriot Dervish Rizai published in Korca "Faith in homeland" (1933). He has written "We are here on this land since it can't be remembered, no homeland no religion, " in "Faith in religion". He admired and had as an idol the great represent ant of the Albanian renaissance, Naim Frasheri, by calling him as "The heart of Albania, the

fountain of wisdom, torch of the childhood, and saint of humanity". (Albanian Encyclopedic Dictionary, 2010)

During the National-Liberation War, the partisan forces were increased, especially the tribes Çongo, Çela, Shimri, Zisko, etc. The martyrs are reminded by the monument at the centre of the village. The village was burned and robbed (1943-1944) by the Germans. In 'Qafa Kashtes' area was developed the battle between the German and partisan forces. The National-Liberation Anti-Fascist Council was set up in March 1943. It was liberated by the V-the offensive Brigade in July 1943.

\section{Economy and lifestyle}

It became a cooperative in 1957, and later it was united with Nartë, Bletëz, Kullollas and Fushëz villages. The first chairperson was Mete Koçi , followed by Bexhet Osuni, Perikli Mali, Fidai Sadiku, Belul Koçi and Misto Perja. In 1967 the village was proclaimed the center of the united cooperative Skenderbegas (Kullollas, Bletëz, Harunas, Nartë, Shëmbërdhenj (Upper), Fushas and Menkollar). The economic activity has always remained the agriculture associated with climatic-terrestrial conditions. There was cultivated mostly wheat (35-40 kvlha), maize (100-140 kvlha), beans (20-22 kvlha), rye (15-18 kv/ha), tobacco, vine, fruit trees, etc. A major part of the work (plowing sowing, harvesting-threshing) were performed with agricultural engineering (old technology). The transport was made by animals, private cargo and the cooperative truck. The storage, separation, etc, were made as elsewhere (typical communist, unfair). Livestock was represented by smaller livestock (350-400 head), cattle (70-80 Cows and animals of work. Vegetables and fodders were also produced. In the 70s the residents received $80 \mathrm{ALL} /$ day/work, while 10 years after result to be 70 all. In 1989 it had an united Middle School (Agriculture), nursery and garden, museum, palace of culture, hospital, shops with mixed articles (Dictionary, 1986) 
After 1990 some new houses have been built, but 30-40\% has maintained the architectural tradition.

The funding is supported by the immigration's income, mainly from Greece. Buildings have many new architectural elements, more functional for the lives of the house wife such as drinking water; .

The main direction in the economic development has historically been the agriculture, vineyards and livestock. In this commune there have been major agricultural

damages (28 July 1978) from hail. The tobacco, vegetables, potatoes, corn, etc. were damaged more severely. In the '70' 80 it was in the centre of the united cooperative-village with the same name (1950 inhabitants). Today it is the centre of the commune (Upper Shëmbërdhenj, Bletëz, Ermenj, Fushëz, Harunas, Kullollas, Kotka, Nartë, Lemnushë, Siman, Vidhan and Zenelas). In the '80s in wheat and potatoes were respectively taken 30-32 kvlha and 140-145 kvlha. The cooperative was among prominent in Gramsh, even in tobacco production, smaller livestock cattle in concentrated stalls (Nartë, etc.) It had 60 heads of cattlelha in the stalls. A huge development had the beekeeping, which is renewed, relatively well. (Sala, S and Lireza, Q, 2014)

Residents plant what's convenient to them. The inhabitants have paid priority attention to cultivation of the vine, fruit trees, also the olive, which is defined by the market finding and fast profit. There are families who receive economic assistance. Residents produce (craft) brandy, dairy, pickles, figs, almonds and dried vegetables, etc. These products are extremely good, thanks to the sun and climatic-terrestrial conditions. The Production costs are high in comparison with other areas. Priority is still the household consumption. With lots of difficulties, inhabitants find little brandy, grapes, fruit and dairy market. The residents have in their tradition the metal and wood working, just for fun. It is saved just a little the working in handloom, while earlier they prepared clothing, carpets for domestic needs. It is still preserved the tradition of protecting the arable land from erosion. About $60 \%$ of the arable land area was opened in the years 1950-1985. (Archive, 2012)

About $90 \%$ of households have land patent, but a significant area is abandoned and left barren. There are identified are as covered by landslides $4-5$ ha and nearly double of them are facing high erosion. Ownership dispute are resolved by understanding with the local government. The commune's administration has 9 employees. The collected revenues are negligible compared with the salaries that they take. Funding from the state budget, that's not the right way!

For the future, the nature and human resources enable the development of agricultural activity: fruit trees, vine, livestock, beekeeping, potato, tobacco, etc. But politicians and decision- makers have to change many things. They have to consider as priority the local territorial organization and the state's assistance politics for the funding of agriculture. Now days, villagers require assistance to promote the incensement of production.

After the 90-s the number of socio-cultural objects is declined, due to mass dismissals of residents to cities like Gramsh, Elbasan, Tirana, Durres, etc. and in emigration. In all municipalities operate seven businesses, three kindergartens, eight elementary schools, three 9-year-old schools and one high school, located in the centre of the municipality.

\section{Discussion}

From what we have introduced above, it results that Skëndebegas commune has a total area of $80.1 \mathrm{~km} 2$ and a population of about 3, 000 inhabitants. It lies in the district of Gramshi, in central Albania, with generally hilly- mountainous landscape and with hilly- mountain Mediterranean climate.

The commune has 13 villages connected with rural roads between them, and also with the centre of the district, the city of Gramsh. Natural and climatic conditions are favourable for the development of agriculture, livestock and viticulture, but the lack of investment in agricultural mechanics; infrastructure has caused the decreasement of crop yields. Likewise the trading of various products, due to damaged roads is inadequate. The population from year to year has decreased sharply, because residents seek for a better life. In these conditions we recommend that;

The research conducted by the Albanian State, to carry out a comprehensive administrative-territorial reform is imperative too. This commune, such as many others, cannot provide incomes; the administration of this commune is funded by the state. The aim of this reform is to reduce the number of communes, taking as basic criteria their geographical area and number of inhabitants.

The state has to encourage private initiative in the villages of this commune, by supporting them even with soft loans. Finally more caution should be taken to improve the road infrastructure, therefore more investment have to be done. 


\section{References}

Baldaci, A. 1917. Itinerari albanesi, Società Geografica Italiana, Roma

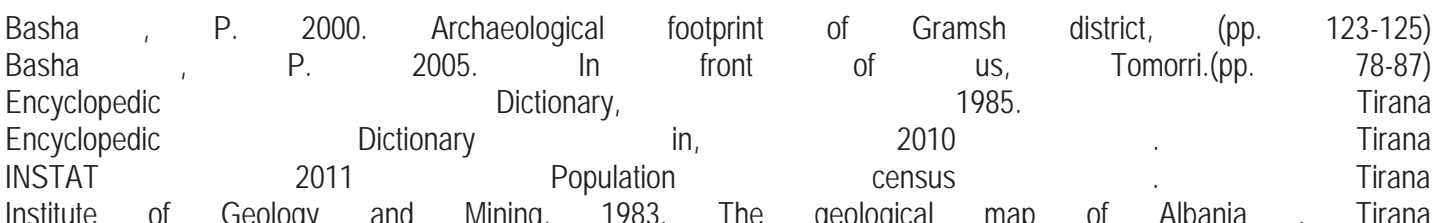
Institute of Geology and Mining, 1983. The geological map of Albania . Tirana Lirëza, Q. 2007. Morphological and morphogenetic features of mountain range, Tomor - Kulmak. (pp. 125-157) Lirëza , Q. 2008. Tourist potentials in the region of Elbasan. UNIEL Bulletin. Elbasan (pp.234-236) Lirëza , 2010 Q. Geomorphological hazards in the area of Tomorrica , Albanian Studies, no 4, Tirana .(pp. 34-49) Lirëza , Q. and Sala , S. 2013. Tomorrica: Natural heritage. Tirana. (pp.203-205) Marishta , S. 2003 . The Geo monuments of Gramsh. Tirana Sala , S and Lirëza , Q. 2014. Nature and people. Monograph Tirana (pp.112-123) The Office of Statistics, 2014- Skenderbegas , Gramsh 